\title{
Correlation analysis of the long latency auditory evoked potential N2 and cognitive P3 with the level of lead poisoning in children
}

\author{
Kátia de Freitas Alvarenga', Gabriela Rosito Alvarez Bernardez-Braga ${ }^{2}$, Fernanda Zucki ${ }^{3}$, Josilene Luciene Duarte ${ }^{4}$, \\ Andrea Cintra Lopes ${ }^{5}$, Mariza Ribeiro Feniman ${ }^{6}$. \\ 1) Speech Therapist; Associate Professor at the Department of Speech Therapy of the College of Dentistry of Bauru/University of São Paulo - FOB/USP, Bauru, São \\ Paulo, Brazil. \\ 2) Speech Therapist, Master in Speech Pathology, Bauru Dental School, University of São Paulo, Brazil \\ 3) Speech Therapist; Master in Communication Disorders by the Universidade Tuiuti do Paraná - UTP/PR. PhD student in Applied Dental Sciences Program of Bauru \\ Dental School/University of São Paulo FOB/USP, Bauru, São Paulo, Brazil. \\ 4) Speech Therapist, Master in Speech Pathology, Bauru Dental School, University of São Paulo, Brazil. PhD student in Applied Dental Sciences Program of Bauru Dental \\ School/University of São Paulo FOB/USP, Bauru, São Paulo, Brazil \\ 5) Speech Therapist; Professor, Doctor, at the Department of Speech Therapy of Bauru Dental School/University of São Paulo FOB/USP, Bauru, São Paulo, Brazil \\ 6) Speech Therapist; Full Professor for the Speech Therapy Course, Bauru Dental School/University of São Paulo FOB/ USP, Bauru, São Paulo, Brazil \\ Institution: Universidade de São Paulo, Faculdade de Odontologia de Bauru, Departamento de Fonoaudiologia, Clínica de Fonoaudiologia \\ Bauru / SP - Brazil. \\ Mailing address: Kátia de Freitas Alvarenga - Faculdade de Odontologia de Bauru Departamento de Fonoaudiologia - Alameda Doutor Otávio Pinheiro Brizola, 9-75 \\ - Vila Universitária - Bauru / SP - Brazil - Zip code: 17043-101 \\ Fundação de Amparo à Pesquisa do Estado de São Paulo \\ Article received, June 29, 2012. Article accepted, November 4, 2012
}

\section{SUMMARY}

Introduction: The effects of lead on children's health have been widely studied.

Aim: To analyze the correlation between the long latency auditory evoked potential N2 and cognitive P3 with the level of lead poisoning in Brazilian children.

Methods: This retrospective study evaluated 20 children ranging in age from 7 to 14 years at the time of audiological and electrophysiological evaluations. We performed periodic surveys of the lead concentration in the blood and basic audiological evaluations. Furthermore, we studied the auditory evoked potential long latency N2 and cognitive P3 by analyzing the absolute latency of the N2 and P3 potentials and the P3 amplitude recorded at Cz. At the time of audiological and electrophysiological evaluations, the average concentration of lead in the blood was less than $10 \mathrm{ug} / \mathrm{dL}$.

Results: In conventional audiologic evaluations, all children had hearing thresholds below $20 \mathrm{dBHL}$ for the frequencies tested and normal tympanometry findings; the auditory evoked potential long latency N2 and cognitive P3 were present in 95\% of children. No significant correlations were found between the blood lead concentration and latency $(p=0.821)$ or amplitude $(\mathrm{p}=0.411)$ of the $\mathrm{P} 3$ potential. However, the latency of the N2 potential increased with the concentration of lead in the blood, with a significant correlation $(\mathrm{p}=0.030)$.

Conclusion: Among Brazilian children with low lead exposure, a significant correlation was found between blood lead levels and the average latency of the auditory evoked potential long latency N2; however, a significant correlation was not observed for the amplitude and latency of the cognitive potential P3.

Keywords: Lead; Lead Poisoning; Evoked Potentials, Auditory; Event-Related Potentials, P300.

\section{INTRODUCTION}

Lead, which is a naturally occurring metal, is widely used in industrial practices and is considered one of the most common environmental contaminants. In this sense, factors such as the generalized contamination of the environment by lead, the wide variety of toxic effects associated with it, and the millions of people affected worldwide independent of the level of nation development, make lead poisoning a public health problem (1).

Aware of these factors, the Center for Disease Control and Prevention (2) pointed out the adverse health effects caused by increasingly lower concentrations of lead in blood.This statement resulted in the review of legislations related to environmental control, and it was proposed that the level of intervention should be changed from $25 \mu \mathrm{g} / \mathrm{dL}$ to $10 \mu \mathrm{g} / \mathrm{dL}$.

However, based on recent scientific evidence, the Advisory Committee on Childhood Lead Poisoning Prevention (ACCLPP) prepared the document "Low Level Lead Exposure Harms Children: A Renewed Call for Primary Prevention". This document recommended replacing the term "level of concern" with "reference value" in all policies, documents, and other publications of the CDC and suggested that current recommendations based on the "level of concern" should be updated according to the recommendations of the report in question. The most 
important recommendations were to change the benchmark of the concentration of lead in blood to $5 \mu \mathrm{g} / \mathrm{dL}$ for children aged 1 to 5 years, and to update this benchmark concentration every 4 years (CDC, 2012) (3).

The issue of lead exposure and its deleterious effects to health in infants began to be recorded in the last century. However, the severity of the problem was recognized only when the scientific evidence began to accumulate, and the initial sense of disbelief regarding the association between lead and its deleterious effects in children became a worldwide concern.

Thereafter, researchers from different parts of the world attempted to present their local findings concerning lead exposure in children through publications. For example, a study from Ecuador investigated the blood concentrations of lead and mercury with the auditory function of schoolage children from a contaminated area (4) and a study from Egypt analyzed the blood lead concentrations and the impact on the cognitive function of children living in areas of low and high lead contamination (5). In Chile, the longterm effects of lead contamination were assessed in children from an agricultural community in the southern part of this country, in which the flour produced by a local plant was contaminated (6). Finally, a study from Canada evaluated the relationship between the neurotoxicity of lead and the potential related to the event (P300) of children from Arctic Québec (7).

In Brazil, several studies (8-10) investigated different trends of lead exposure in children after the occurrence of an ecological accident caused by a battery manufacturing plant located in the city of Bauru/São Paulo. These studies attempted to clarify the aspects related to the impairment to these children's health and raised environmental and social questions that an ecological accident of such proportion is capable of triggering.

The consensus in the international literature is that children with more than $10 \mu \mathrm{g} / \mathrm{dL}$ of lead in their blood can show the following symptoms: deficits in attention, sleep, cognition, psychomotor function, short-term memory, visuospatial abilities, and language as well as apathy, headaches, convulsions, IQ reduction, hearing loss, aggressive behavior, mental retardation, abdominal and joint pain, nephropathy, anemia, and even death $(5,11-$ 16). Recent data have indicated that impairment of cognition, attention, and behavior can occur in children with blood lead concentrations around $3-5 \mu \mathrm{g} / \mathrm{dL}(17,18)$.

The nervous system is considered one of the systems that is most vulnerable to the toxic action of lead, and studies have shown that the peripheral as well as the central portion of this system can be affected. However, children appear to be much more susceptible to alterations of the central nervous system (19-20).

A consensus has not been reached about the influence of lead in the auditory system or which portion, peripheral and/or central, would be altered (4, 8, 21-23).

One of the examination methods used to evaluate auditory processing and its association with lead is the cognitive auditory evoked potential P3, which is defined as a neurophysiological procedure that can beused to measure the cerebral processes that are necessary for cognitive functioning but cannot be observed directly through behavior (7). This potential is a response from an individual to a target stimulus within a series of occasionally different stimuli. Intracranial or electromagnetic records of surfaces suggests that the generation of this potential is related to multiple local cortical areas such as the frontal cortex, the central parietal cortex, and the auditory cortex, thus involving cognitive and auditory functions (24).

Research studies that used the cognitive potential P3 for evaluating lead-exposed individuals and a control group presented findings that range from latency delay $(25,26)$, reduction of the amplitude of the $\mathrm{P} 3$ component (7), to the absence of an association between the P300 and the blood lead concentration (22).

Thus, the objective of the present study was to analyze the correlation of the long latency auditory evoked potential N2 and cognitive P3 with the level of lead poisoning in Brazilian children.

\section{MethOD}

This transverse study was approved by the Ethics Committee of the institution (process number 27/2005). All adults who were legally responsible for the children who participated in the study received an orientation, signing a Term of Free and Clarified Consent after reading the patient information letter.

\section{Selection of the Casuistry}

Children aged between 7 and 14 years with a history of lead poisoning and whose blood lead concentration was above $10 \mu \mathrm{g} / \mathrm{dL}$ in the first blood sample obtained were selected. The Health Department of the city of Bauru in the state of São Paulo, Brazil, was responsible for the lead poisoning analysis, which was carried out in 4 stages over a period of 2 years. The values of lead concentration found in the blood of the selected children are presented in Figure 1 . 


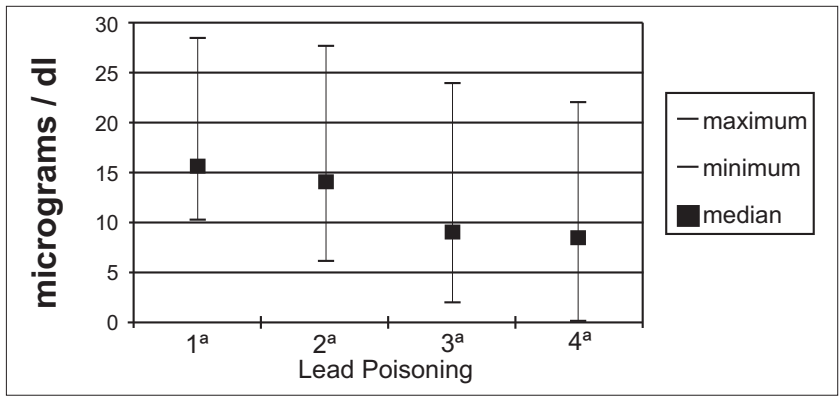

Figure 1. Median lead poisoning values and the standard deviation in 4 blood samples obtained from the children during the period 2002 to 2004 .

The audiological and electrophysiological evaluations were carried out between the third and fourth blood collections, in which the median lead concentration level was lower than $10 \mu \mathrm{g} / \mathrm{dL}$. However, for the purpose of analysis, individual lead concentration values were considered.

\section{Casuistry}

The study participants were 20 children with low levels of lead poisoning (13 males and 7 females).

\section{Basic Audiological Evaluation}

Initially, anamnesis was used in order to obtain information about risk factors for auditory deficiency or mental alterations that could interfere with the results. Children with these conditions were excluded. A Madsen audiometer, a Midmate model 622 with TDH-39 phones, and an immittanciometer (Interacoustics, model AZ 7), were used for the conventional audiological evaluation, which consisted of liminar tonal audiometry, the speech recognition threshold, and tympanometry. The following parameters were used to indicate the absence of hearing loss: auditory thresholds $\leq 20 \mathrm{~dB} H L(27)$, a frequency range of $500-4 \mathrm{kHz}$, and a tympanometry curve type $\mathrm{A}(28)$.

\section{Long Latency Auditory Evoked Potential N2 and Cognitive $P 3$}

The long latency evoked potential N2 and cognitive P3 were determined using the Biologic Evoked Potential System (EP) in a quiet room, with $3 \mathrm{~A}$ insertion phones. Disposable electrodes for electroencephalography, AG/ AGCL model, with an individual impedance lower than 5 KW and impedance inter-electrodes lower than $2 \mathrm{KW}$ were used. The active electrodes were placed in $\mathrm{Cz}$ and $\mathrm{Fz}$ and connected to input 1 of channels 1 and 2, respectively, of the pre-amplifier. The reference electrode was located in the right mastoid, in input 2 of channel 1, and was interconnected to channel 2 by jumper of the pre-amplifier. The ground electrode was placed in the Fpz position. The electrodes were arranged according to the ten-twenty electrode system (29).

The examination was carried out with the child lying comfortably with their closed eyes to eliminate artifacts caused by eye movement.

The stimulus used was a 2000-Hz frequency rare tone burst with infrequent presentation (oddball paradigm), unexpected and random, with a $20 \%$ probability of the presentation of another 1000-Hz frequency tone burst stimulus presented with an $80 \%$ probability, with a moderate intensity ( $80 \mathrm{~dB}$ HL). The presentation rate was 1 stimulus per second, with a filter passband from 1 to $25 \mathrm{~Hz}$. The initial record received a low pass digital filter with a cutoff frequency of $25 \mathrm{~Hz}$. The child was asked to identify the rare stimulus through a hand signal.

\section{Evaluation Parameters}

The absolute latency ( $\mathrm{ms}$ ) of the $\mathrm{N} 2$ and $\mathrm{P} 3$ potentials and the amplitude $(\mathrm{mV})$ of the $\mathrm{P} 3$ registered in $\mathrm{Cz}$ were analyzed. The $\mathrm{N} 2$ and $\mathrm{P} 3$ potentials were considered to be present when a stimulus was recorded in $\mathrm{Fz}$ and $\mathrm{Cz}$ simultaneously, as proposed in a previous study (30).

The results obtained in $\mathrm{Cz}$ were subjected to descriptive statistical analysis (average, median, standard deviation, minimum value, and maximum value) and to Pearson's coefficient of correlation in order to verify the correlation between the level of lead poisoning and the latency values of the N2 and P3 potentials and the amplitude of $\mathrm{P} 3$. The significance level used was $\mathrm{p} \leq 0.05$.

\section{RESULTS}

In the conventional audiological evaluation, all children presented hearing thresholds lower than $20 \mathrm{~dB} H \mathrm{HL}$ for all of the tested frequencies. Tympanometry demonstrated normal functionality of the spandrel-ossicular system.

The descriptive statistical analysis of the latency values of the N2 and $\mathrm{P} 3$ potentials and the amplitude of $\mathrm{P} 3$ obtained in the evaluated children are presented in Table 1.

The result of the Pearson's coefficient of correlation for the values of lead poisoning found in the blood of all 
Table I. Descriptive analysis of the latency values (ms) of the N2 and P3 potentials and the amplitude $(\mu \mathrm{V})$ of $\mathrm{P} 3$

\begin{tabular}{lccccc}
\hline Variable & Mean & Median & StandardDeviation & Minimum & Maximum \\
\hline N2-latency & 223.33 & 217.29 & 38.12 & 185.54 & 359.99 \\
P3-latency & 331.46 & 327.12 & 43.00 & 275.07 & 433.30 \\
P3-amplitude & 6.27 & 5.74 & 3.63 & 1.77 & 13.85 \\
\hline
\end{tabular}

* $\mathrm{p} \leq 0.05$ : statistically significant.

evaluated children, the latency of the $\mathrm{N} 2$ and $\mathrm{P} 3$ potentials, and the amplitude of the $\mathrm{P} 3$ are presented in Table 2.

\section{DisCUSSION}

The present study was performed in children with a history of lead exposure, which indicates an initial lead concentration higher than the maximum limit of blood lead considered acceptable (10 $\mu \mathrm{g} / \mathrm{dL})$ (2). Follow-up measurements of blood lead level in the 20 children demonstrated a reduction in the median blood lead concentration over the period of the 4 analyses: the median lead concentration level was almost $15 \mu \mathrm{g} / \mathrm{dL}$ in the first and second collections, but was below $10 \mu \mathrm{g} / \mathrm{dL}$ in third and fourth collections (Figure 1). This result was obtained from the establishment and execution of actions that aimed to reduce the lead exposure of the population in the contaminated area, through the complete recovery of the soil, underground and surface waters, and vegetation.

The toxic nature of lead allows it to affect numerous biological activities. Lead promotes alterations that range from the biochemical to the clinical level due to its capacity to reach and accumulate in almost all organs of the human body, especially the central nervous system, and its most deleterious effects are observed after long-term exposure (31).

Several mechanisms have been proposed to explain the neurotoxic actions of lead. These include biophysical alterations of the cellular membrane, alterations in cellular signaling, loss of neurotransmitters, and oxidative stress. Oxidative stress causes free radical accumulation that can result in dysfunctions and cellular death; this mainly occurs in neuronal cells because they are highly sensitive to free radicals (32). Thus, it is believed that lead affects several biologically significant processes, including energetic metabolism, apoptosis, protein maturation, and genetic regulation.

The molecular alterations previously described can interfere with important processes during neurological and psychiatric development. Brain damage caused by lead occur mainly in the prefrontal cortex, cerebellum, and
Table 2. Values of Pearson's coefficient of correlation when comparing median lead poisoning and the long latency auditory evoked potential

\begin{tabular}{lccc}
\hline \multicolumn{4}{c}{ LongLatency Auditory EvokedPotential } \\
MedianLeadPoisoning & N2 & P3 & P3amp \\
\hline$R$ & 0.4854 & 0.0574 & -0.2066 \\
$P$ & 0.030* & 0.821 & 0.411 \\
\hline
\end{tabular}

* $\mathrm{p} \leq 0.05$ : statistically significant.

hippocampus, which are the regions responsible for cognitive function, execution of motor skills, and memory, respectively (33).

A consensus does not exist in the literature regarding the blood lead concentration that is harmful to the auditory system. Some studies demonstrated that exposure to lead, even at low concentrations, harms hearing $(34,35)$ and nervous conduction in the auditory system (35). On the other hand, other studies $(7,26)$ stated that blood lead concentrations between 30 and $40 \mu \mathrm{g} / \mathrm{dL}$ are necessary to affect the latency of the cognitive potential P3.

Although the present study evaluated children who did not exhibit hearing loss, an important finding was obtained with regard to the auditory attention ability necessary for processing the acoustic signal.

The cognitive potential $\mathrm{P} 3$ was recorded in 19 children (95\%). Similar to the studies mentioned previously, no significant correlation was found between the latency and the amplitude of the cognitive potential P3 and the average lead concentration (Table 2). This finding is probably justified by the fact that the children had lead concentrations higher than $30 \mu \mathrm{g} / \mathrm{dL}$ (Figure 1).

However, a significant correlation was found between the latency of the auditory potential N2 and the average lead concentration, demonstrating that the children with a high blood lead concentration had the highest latency values of the N2 potential (Table 2). Given that the N2 potential is endogenous and highly related to attention (36), this finding suggests that children with lead contamination can exhibit attention deficit, as described in a previous study (12). 
Attention is a multimodal process that is essential for processing selected information and, consequently, for learning. Therefore, it is important to highlight the importance of behavioral evaluation of the auditory abilities, especially auditory attention, in children with low lead exposure in order to identify possible alterations and to consider appropriate interventions for preventing delays in the global and academic development of the child.

\section{CONCLUSION}

We found a significant correlation between the median lead poisoning value and the latency of the long latency auditory evoked potential N2 in Brazilian children with lead poisoning, but a similar correlation was not found for the latency and amplitude of the cognitive potential P3.

\section{ACKNOWLEDGEMENTS}

We thank the Fundação de Amparo à Pesquisa do Estado de São Paulo, process number 05/50163-7, for their assistance.

\section{REFERENCES}

1. Olympio KPK, Oliveira PV, Naozuka J, Cardoso MRA, Gunther WMR, Bechara EJH. Surface dental enamel lead levels and antisocial behavior in Brazilian adolescents. The Toxicologist (Supplement to Toxicological Sciences). 2009;108(1):76-77.

2. CDC. Preventing lead poisoning in young children. Atlanta: US Department of Health and Human Services, Public Health Service, 1991.

3. CDC. CDC response to Advisory Committee on Childhood Lead Poisoning Prevention recommendations in "Low level lead exposure harms children: a renewed call for primary prevention." Atlanta, GA: US Department of Health and Human Services, CDC; 2012.

4. Counter SA, Vahter M, Laurell G, Buchanan LH, Ortega F, Skerfving S. High lead exposure and auditory sensoryneural function in andean children. Environ Health Perspect. 1997;105(5):522-526.

5. Mostafa GA, El-Shahawi HH, Mokhtar A. Blood lead levels in Egyptian children from high and low lead-polluted areas: impact on cognitive function. Acta Neurol Scand. 2009;120:30-37.
6. Coria C, Cabello A, Tassara E, López E, Rosales H, Pérez $\mathrm{M}$, et al. Efectos clínicos a largo plazo en niños intoxicados con plomo en una región del sur de Chile. Rev. Méd. Chile. 2009;137:1037-44.

7. Boucher O, Muckle G, Saint-Amour D, Dewailly E, Ayotte P, Jacobson SW et al. The relation of lead neurotoxicity to the event-related potential $\mathrm{P} 3 \mathrm{~b}$ component in Inuit children from arctic Québec. NeuroToxicology. 2009;30:1070-77.

8. Alvarenga KF. 2005. Avaliação do sistema auditivo periférico e central em crianças com histórico de contaminação por chumbo [Livre-Docência]. Bauru: Faculdade de Odontologia de Bauru da Universidade de São Paulo; 2005.

9. Tomita NE, Padula NAMR. Intoxicação por chumbo em criancas e o discurso da imprensa. Cienc Saúde Coletiva. 2005;10(Supl):111-9.

10. Padula NAMR, Abreu MH, Miyazaki LCY, Tomita NE. Intoxicação por chumbo e saúde infantil: ações intersetoriais para o enfrentamento da questão. Cad Saúde Pública. 2006;22(1):163-71.

11. Canfield RL, Henderson CR, Cory-Slechta DA. Intellectual impairment in children with blood lead concentrations below 10 microgram per deciliter. New Engl J Med. 2003;348,151726.

12. Bellinger D. Very low lead exposures and children's neurodevelopment. Curr Opin Pediatr. 2008;20:172-77.

13. Min MO, Singer LT, Kirchner HL, Minnes S, Short E, Hussain Z. et al. Cognitive development and low-level lead exposure in poly-drug exposed children. Neurotoxicology and Teratology. 2009;31:225-231.

14. Abelsohn AR, Sanborn M. Lead and children: clinical management for family physicians. Can Fam Physician. 2010;56(6):531-5.

15. Eubig PA, Aguiar A, Schantz SL. Lead and PCBS as risk factors for attention deficit/hyperactivity disorder. Environ Health Perspect. 2010;118(12):1654-67.

16. Boucher O, Jacobson SW, Plusquellec P, DeWailly E, AyotteP, Forget-Dubois N, Jacobson JL, Muckle G. Prenatal methylmercury, postnatal lead exposure, and evidence of attention deficit/hyperactivity disorder among inuit children in Arctic Québec. Environ Health Perspect. 2012 oct; 120(10):1456-61.

17. Chiodo LM, Jacobson SW, Jacobson JL. 
Neurodevelopmental effects of postnatal lead exposure at very low levels. Neurotoxicol. 2004;26:359-71.

18. Chiodo LM, Covington C, Sokol RJ, Hannigan JH, Jannise J, Ager J, et al. Blood lead levels and specific attention effects in young children. Neurotoxicol. Teratol. 2007;29:538-46.

19. World Health Organization. International Programme on Chemical Safety. Environmental Health Criteria 165: Inorganic Lead. Finland: Vammala, 1995.

20. Toscano CD, Guilarte TR. Lead neurotoxicity: from exposure to molecular effects. Brain Res Rev. 2005;49:529554.

21. Discalzi GL, Capellaro F, Bottalo L, Fabbro D, Mocellini A. Auditory brain-stem evoked-potentials (BAEPS) in leadexposed workers. Neurotoxicol. 1992;13(1):207-9.

22. Monteiro LP, Faria FV, Ferreira MV, Alvarenga KF, Martins $\mathrm{CH}$, Costa OA, et al. Efeitos da exposição ao chumbo e ao ruído sob o sistema auditivo periférico e central; estudo eletrofisiológico. In: 18o. Encontro Internacional de Audiologia, 2003, Curitiba. 18․ Encontro Internacional de Audiologia, 2003.

23. Alvarenga KF, Jacob LCB, Martins CHF, Costa Filho OA, Coube CZV, Marques JM. Emissões otoacústicas - produto de distorção em indivíduos expostos ao chumbo e ao ruído. Rev Bras Otorrinolaringol. 2003;69(5):681-689.

24. Musiek FE, Lee WW. Potenciais auditivos de média e longa latência. In: Musiek FE, Rintelmann WF, editores. Perspectivas atuais em avaliação auditiva. Barueri: Manole, 2001. p. 239-67.

25. Araki S, Murata K, Yokoyama K, Uchida E. Auditory eventrelated potencial (P300) in relation to peripheral nerve conduction in workers exposed to lead, zinc, and copper: effects of lead on cognitive function and central nervous system. Am. J. Ind. Med. 1992;21:539-47.

26. Hirata M, Kosaka H, Yoshida T. A Study on the effect of lead on event-related potentials among lead-exposed workers. Industrial Health. 2004;42:431-4.
27. World Health Organization. Prevention of blindness and deafness: Grades of hearing impairment. Disponível em: http://http://www.who.int/pbd/deafness/ hearing_impairment_grades/en/Acessadoem: 15/10/2012.

28. Jerger J. Clinical experience with impedance audiometry. Arch Otolaryngol Head Neck Surg. 1970;92(4):311-324.

29. Jasper HH. The ten-twenty electrode system of the International Federation. Electroencephalogr Clin Neurophysiol 1958;10:371-375.

30. Duarte JL, Alvarenga KF, Banhara MR, Melo ADP, Sás RM, Costa Filho AO. Potencial evocado auditivo de longa latência-P300 em indivíduos normais: valor do registro simultâneo em Fz e Cz. Braz J Otorhinolaryngol. 2009;75(2):231-6.

31. Verstraeten N, Braeken K, Debkumari B, Fauvart M, FransaerJ, Vermant J, Michiels J. Living on a surface: swarming and biofilm formation. Trends in Microbiology. 2008;16:496506.

32. Adhikari A, Penatti CA, Resende RR, Ulrich H, Britto LR, Bechara EJH. 5-Aminolevulinate and 4,5-dioxovalerate ions decrease GABA(A) receptor density in neuronal cells, synaptosomes and rat brain. Brain Res, 2006;1093:95-104.

33. Repko JD, Corum CR. Critical review and evaluation of the neurological and behavioral sequelae of inorganic lead absorption. CRC Crit Ver Toxicol. 1979;6:135-87.

34. Forst LS, Freels S, Persky V. Occupational lead exposure and hearing loss. J Occup Environm Med. 1997;39(7):658660 .

35. Gomes H, Molholm S, Christodoulou C, Ritter H, Cowan $\mathrm{N}$. The development of auditory attention in children. Front Biosc. 2000;1(5):108-20.

36. McPherson DL, Ballachanda B. Middle and Long Latency Auditory Evoked Potentials. In: Roeser RJ, Valente M \& Hosford-Dunn H (org). Audiology Diagnosis. New York: Ed Thieme, 2000. p. 471-501. 